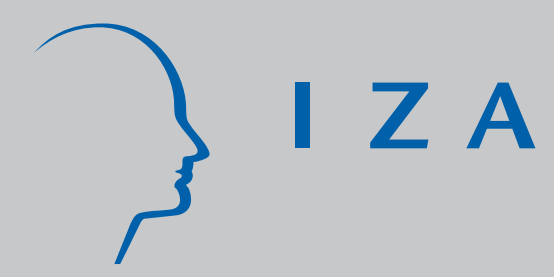

IZA DP No. 2084

Income Inequality and J ob Satisfaction of Full-Time Employees in Germany

Christoph Wunder

J ohannes Schwarze

April 2006 


\title{
Income Inequality and Job Satisfaction of Full-Time Employees in Germany
}

\author{
Christoph Wunder \\ University of Bamberg
}

\author{
Johannes Schwarze \\ University of Bamberg, DIW Berlin \\ and IZA Bonn
}
Discussion Paper No. 2084
April 2006

IZA

P.O. Box 7240

53072 Bonn

Germany

Phone: +49-228-3894-0
Fax: +49-228-3894-180
Email: iza@iza.org

Any opinions expressed here are those of the author(s) and not those of the institute. Research disseminated by IZA may include views on policy, but the institute itself takes no institutional policy positions.

The Institute for the Study of Labor (IZA) in Bonn is a local and virtual international research center and a place of communication between science, politics and business. IZA is an independent nonprofit company supported by Deutsche Post World Net. The center is associated with the University of Bonn and offers a stimulating research environment through its research networks, research support, and visitors and doctoral programs. IZA engages in (i) original and internationally competitive research in all fields of labor economics, (ii) development of policy concepts, and (iii) dissemination of research results and concepts to the interested public.

IZA Discussion Papers often represent preliminary work and are circulated to encourage discussion. Citation of such a paper should account for its provisional character. A revised version may be available directly from the author. 
IZA Discussion Paper No. 2084

April 2006

\section{ABSTRACT}

\section{Income Inequality and Job Satisfaction of Full-Time Employees in Germany}

Using data from the German Socio-Economic Panel Study (GSOEP), it is shown that income comparison with persons who are better off has a clear impact on the job satisfaction of West German full-time employees. Two contrary effects can be identified. On the one hand, there is an aversion to disadvantageous regional income inequality, while on the other hand, individuals prefer inequality within their occupational group. The two effects are interpreted as envy and an information (or "tunnel") effect, respectively. The analysis of income comparison with persons who are worse off suggests a prestige effect. However, downward comparison is of minor importance for job satisfaction.

JEL Classification: D63, I31, D31

Keywords: job satisfaction, income inequality, social comparison, envy, prestige, information effect (tunnel effect), German Socio-Economic Panel Study (GSOEP)

Corresponding author:

Christoph Wunder

Bamberg University

Department of Economics

Feldkirchenstraße 21

D-96045 Bamberg

Germany

E-Mail: christoph.wunder@sowi.uni-bamberg.de 


\section{Introduction}

A standard assumption of the neoclassical framework is that utility is derived from income by using it as a means of consumption of goods. However, income not only provides direct utility from consumption but may also have an indirect impact on individual welfare because relative position in the income distribution constitutes a person's social status.

Veblen (1994) supposed a close relationship of consumption and the social status. In his "Theory of the Leisure Class", consumption is both a source of direct utility and an expression of striving for social status. By conspicuous consumption, an individual signals possession of certain socio-economic characteristics that cannot be directly observed by other people. The demonstration of such characteristics promotes other people's good opinion of the agent, which in turn increases his/her welfare.

Since the seminal study of Easterlin (1974) the influence of relative income on subjective well-being is on the agenda for empirical research. Building on the idea that an individual's welfare function of income is equivalent to a (perceived) distribution of income (an idea that includes social comparison because any income level is evaluated by its rank in the distribution of income), van de Stadt et al. (1985) find empirical evidence for the hypothesis that utility is relative. Clark and Oswald (1996) choose a different approach. Utilizing the job satisfaction question in the British Household Panel Survey (BHPS), they show that comparison income (which is defined as the predicted income from an earnings regression) has a negative impact on job satisfaction. Senik (2005) provides an overview of empirical studies that investigate the relationship between the distribution of income and well-being. Further examples are Luttmer (2005) who scrutinizes the impact of local earnings on well-being - his findings indicate a substantial, negative effect of the income of persons living in the environs on well-being - and D'Ambrosio and Frick (2004) who demonstrate a direct linkage between the concepts of relative deprivation and subjective well-being.

Naturally, these findings raise the question why relative income matters at all. An answer has to consider the process of social comparison. Festinger (1954) in his "Theory of Social Comparison Processes" formulates the hypothesis that "people evaluate their opinions and abilities by comparison respectively with the opinions and abilities of others" 
(p. 118). ${ }^{1}$ In addition, Singer (1966) points out that the process of social comparison provides individuals with information about themselves, which is the basis for self-esteem: “When a person asks 'How much X do I have?' he is also asking 'What sort of person am I for possessing that much X?' " (p. 105). Consequently, social comparison is constitutive for social status and, with it, for self-approval.

This paper adopts the idea that humans derive well-being from their social status. It concentrates on the social status obtained from labor income. An attempt is made to model and to estimate empirically the impact of social comparison on individual welfare. The empirical analysis focuses primarily on two questions. The first question is whether social comparison has a direction, i.e., is social comparison directed upward or downward? The second question concerns what preferences individuals have for income inequality. Such preferences can be derived from the (positive or negative) welfare effects that result from social status.

The paper is arranged as follows. In Section 2 some theoretical considerations are made about how the process of social comparison can be implemented in a utility function. The specification of the econometric model and a short description of the data can be found in Section 3. The estimation results are presented in Section 4. Section 5 concludes.

\section{Well-Being and Social Comparison}

Assuming that, apart from consumption, social status mediated by relative income position yields utility, the utility function of an individual $i$ can be written as

$$
U_{i}=U\left(V\left(y_{i}, F_{i}\right), S\left(y_{i}, y_{j}\right)\right)
$$

where $U_{i}$ denotes the well-being or utility level of a person $i$. Utility is, on the one hand, a function $V$ of own income $y_{i}$ and leisure $F_{i}$. The value of the function $V\left(y_{i}, F_{i}\right)$ gives information about how the income is used in welfare-relevant consumption and how much satisfaction is derived from leisure $(\partial U / \partial V>0)$. It is assumed that both a rise in income

\footnotetext{
${ }^{1}$ Differences in income can be regarded as a difference in ability because (labor) income is a monetary equivalent of an individual's productive ability.
} 


\section{Figure 1}

\section{Well-being and social comparison}

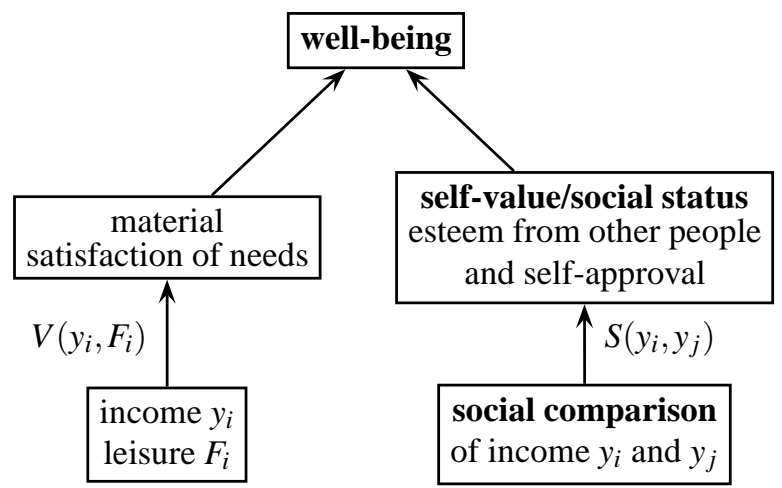

and additional leisure increases utility $\left(\partial V / \partial y_{i}>0\right.$ and $\left.\partial V / \partial F_{i}>0\right)$. On the other hand, welfare results from the function $S\left(y_{i}, y_{j}\right)$, which captures the impact of social comparison. The variable that is relevant for comparison is income. The value of $S\left(y_{i}, y_{j}\right)$ is a measure of the contentment derived from social status. Following Dakin and Arrowood (1981), this component is denoted self-value.

The function $S$ captures two effects of social comparison on well-being. Firstly, from the process of social comparison people get information about whether they are esteemed by the members of the reference group. Secondly, the relative income position in the reference group is also an important yardstick of self-approval. The distribution of income represents an Archimedean point that forms the basis of a judgment of one's own success or failure. Figure 1 illustrates the constitutive importance of the process of social comparison for well-being. Therefore, an investigation of well-being that results from relative income position has to concentrate on social comparison.

How can the mechanism of self-value be described in more detail? It is assumed that income is a suitable indicator for the social status and that the self-value results from a comparison of income. Thus, the self-value can be generally understood as a function of the difference in income, i.e., $S=f\left(y_{i}-y_{j}\right)$. Similar approaches that operate by calculating the difference in certain variables have been used to analyze the impact of social comparison, for example, by Dakin and Arrowood (1981), Loewenstein et al. (1989) and Fehr and Schmidt (1999). In order to distinguish between comparisons with people who are poorer and those who are richer, the income of all $n$ persons in the reference group is sorted so that $y_{1}^{P}<\ldots<y_{i-1}^{P}<y_{i}<y_{i+1}^{R}<\ldots<y_{n}^{R}$. All incomes that are smaller (larger) 
than that of comparing person $i$ are assigned to individuals of a lower (higher) social status. In consequence, two comparison groups exist within the reference group: the richer and poorer reference individuals. In addition, it is assumed that a person compares him or herself with all persons in each reference group. Thus, the function $S$ can be written as

$$
S=\frac{a}{n-1} \sum_{j=i+1}^{n}\left(y_{j}^{R}-y_{i}\right)+\frac{b}{n-1} \sum_{j=1}^{i-1}\left(y_{i}-y_{j}^{P}\right)
$$

where $n \geqslant 2$. The first sum on the right hand side of equation 2 measures the disadvantageous inequality that results from the comparison with richer individuals. It can be interpreted as an indicator of the relative deprivation of individual $i$ (cf. Runciman 1966; Yitzhaki 1979). The second sum represents the comparison with the poorer ones, i.e., the advantageous inequality. It is the counterpart of the relative deprivation and can, therefore, be denoted as relative satisfaction. Additionally, the aggregate differences in income are normalized by dividing by the number of persons in the reference group (minus one for the comparing person), which yields the average difference in income. Including the parameters $a$ and $b$, the upward and the downward comparison can enter the self-value with a different weight. For example, from $|a| \ggg|b|$ it follows that comparison with richer people has a stronger impact on the self-value than comparison with poorer ones.

The specification of self-value is similar to the way Fehr and Schmidt (1999) model the social comparison. The authors formulate a theoretical approach in which they assume, however, inequality aversion. In particular, they exclude the existence of individuals who want to be better off than others. And/or they consider those people at least as irrelevant for their analysis. In contrast, this study imposes no a priori restrictions on the parameters $a$ and $b$. It pursues, rather, the investigation of preferences concerning inequality as revealed in fieldwork. Thus, the following interpretations of the parameters are possible:

Information effect $a>0$ : Considering the richer reference individuals, the self-value rises with the average difference in income. This implies a preference for disadvantageous income inequality. In this case, inequality increases well-being because the individual interprets it as a signal for a future improvement of his own relative position in the income 
distribution. Hirschman and Rothschild (1973) denote this phenomenon as a tunnel effect, which is an analogy from traffic. In a traffic jam on a road with two lanes, the vehicles that begin to move in one lane give a signal to those in the stationary cars in the other lane. The drivers of the stationary cars anticipate the dissolution of the traffic jam and an imminent resumption of their travel.

In the context of an investigation of the welfare effects of social comparison, the analogy can be made precise as follows. Apart from present income, welfare depends on the expected growth of income in the future. However, individuals have only a little information concerning their future income. In order to improve their informational basis, they try to predict their financial future on the basis of the present situation of people in comparable circumstances. If a favorable development in the financial situation of other persons is perceived and this development is attributed to the economic environment, then they may expect to benefit from this development in the future. The expectation of financial progress may, as a result, induce a positive welfare effect.

Hirschman and Rothschild (1973) deduce a Pareto improvement from the tunnel effect because "everybody feels better off, both those who have become richer and those who have not" (p. 548). Admittedly, the authors mention the problem that the social climbers cannot realize their hope for a welfare improvement, because a substantial obstacle exists in the lack of acceptance by older elites who would discriminate against the nouveau riche. $^{2}$ However, they disregard a problem included in the model: self-deception. The tunnel effect can lead to a lower welfare level in the long run when the individual manages to improve his/her relative income, i.e., when the average difference in income with respect to richer individuals is reduced. This is a consequence of the fact that an increase in income is associated with the abandonment of hope for such an improvement. If the loss of hope is not compensated by a utility gain from material consumption or an increase in prestige, it can lead to a (net) welfare loss even when social mobility is granted, i.e., when the social climbers are accepted by the old elites.

\footnotetext{
${ }^{2}$ Beyond that, Hirschman and Rothschild (1973) discuss a further problem. The social climbers could have an inequality aversion and could be discontented with their own social advancement because other people remain in an inferior income position. However, the specification of self-value as social comparison in equation 2 permits us to ignore this effect here because the comparison with poorer individuals is modeled on the basis of the parameter $b$.
} 
Envy $a<0$ : Well-being decreases with an increase in the average disadvantageous inequality. A person prefers a distribution of income in which he or she is not financially worse off compared to other people. Such a preference might be closely associated with the suspicion that there is probably something unfair going on, e.g., individuals have the opinion that their performance or productivity is not inferior to that of wealthier people and that, therefore, the monetary evaluation of the market is inappropriate.

Prestige $b>0$ : The larger the average difference in income with respect to poorer reference individuals is, the higher the contentment with one's own achievement. This positive welfare effect can be interpreted as a prestige effect. In this case, a person perceives the approval of other persons for his or her own performance, which leads to a higher self-value. Beyond that, higher prestige is often accompanied with an (at least informal) expansion of the sphere of influence that extends the actual scope of action.

Regret $b<0$ : The larger the average difference in income with respect to the poorer reference persons is, the smaller the own welfare from the self-value is. The reason for the welfare loss, which enlarges with an increase in own income, can result, on the one hand, from the fact that one does not experience approval for one's performance from the poorer members of the reference group. On the other hand, the welfare loss can also be a consequence of one's disapproval for the poorer persons' performance. Such a feeling of disapproval stems from a concrete disadvantage for the person who is evaluating him/herself. To illustrate this issue, suppose a situation in which co-operation exits in the reference group, for example, concerning the supply and financing of a public good. Individuals are assumed to be identical with respect to their productive ability. However, there are persons who do not make use of their full productive ability and are, hence, poorer. In other words, the less productive members of the reference group are considered free-riders because their insufficient performance may result in larger contributions from those who fully exploit their productive abilities. The richer persons' feeling of a lower self-value may result from the fact that they experience a higher financial burden and regard themselves as the losers in the co-operative relationship. 
While the two categories envy and regret are closely associated with an aversion to inequality (that can equivalently be interpreted as risk aversion), the prestige and information effects imply a preference for inequality. A social and economic policy that makes use of incentives based on income inequality (e.g., when lowering welfare benefits and reducing taxation of labor income) will be appropriate for increasing the social welfare if the preferences concerning income distribution can be characterized by the prestige and information effects. If, in contrast, envy and regret determine the individuals' self-value, the same policy will lead to a reduction in well-being (at least concerning self-value). No general preference for and/or aversion to inequality follows from the preference combinations prestige/envy and regret/information effect. Table 1 gives an overview.

\section{Table 1}

\section{Preferences for inequality deduced from the self-value}

\begin{tabular}{|l|l|l|}
\hline & information effect $a>0$ & envy $a<0$ \\
\hline $\begin{array}{l}\text { prestige } \\
b>0\end{array}$ & general preference for inequality & $\begin{array}{l}\text { preference for advantageous inequality, } \\
\text { aversion to disadvantageous inequality }\end{array}$ \\
\hline $\begin{array}{l}\text { regret } \\
b<0\end{array}$ & $\begin{array}{l}\text { preference for disadvantageous inequality, } \\
\text { aversion to advantageous inequality }\end{array}$ & $\begin{array}{l}\text { general aversion to inequality, or risk } \\
\text { aversion }\end{array}$ \\
\hline
\end{tabular}

\section{Econometric Model and Data}

The process of social comparison of people in the labor market is the main topic of the empirical analysis. One can assume that (gross) labor income is a meaningful indicator of social status because workers who sell their labor to firms are to a certain extent in a competitive situation. Thus, it seems plausible to suppose that income is relevant to the process of social comparison.

First of all, the empirical evaluation of the welfare effects of social comparison requires a specification of the utility function. The self-value $S$ was introduced and discussed above, so that an econometric model can be written as follows.

$$
S W B_{i}=\beta_{0}+\beta_{1} \frac{1}{n-1} \sum_{j=i+1}^{n}\left(y_{j}^{R}-y_{i}\right)+\beta_{2} \frac{1}{n-1} \sum_{j=1}^{i-1}\left(y_{i}-y_{j}^{P}\right)+\beta_{3} \ln y_{i}+\beta_{4} \ln H_{i}+\mathbf{x}_{i}^{\prime} \boldsymbol{\beta}+\eta_{i}
$$


The material satisfaction of needs is modeled as logarithm of income, $\ln y_{i}$. Logarithmic working time, $\ln H$, is substituted for leisure in the utility function. In addition, utility depends on individual and institutional characteristics $\mathbf{x}$. The parameters of interest are denoted $\beta$. In particular, $\beta_{1}$ and $\beta_{2}$ are empirical values for the parameters $a$ and $b$ of self-value. $\eta$ is an error term. $S W B$ represents subjective well-being.

The German Socio-Economic Panel Study (GSOEP) provides the data required. The GSOEP is a representative longitudinal study of private households in the Federal Republic of Germany that was started in 1984. The same persons are surveyed annually (cf. Haisken-DeNew and Frick 2005). This paper makes use of ten waves from 1995 to $2004 .^{3}$

The employees' utility is approximated by their job satisfaction, which is captured by the following survey question:

“How satisfied are you with your job?” (Infratest Sozialforschung 2004)

Job satisfaction is assessed on a scale from 0 (totally unhappy) to 10 (totally happy). Among economists, subjective well-being is a widely accepted approximation for utility. Therefore, Frey and Stutzer (2002) discuss the integration of happiness research into economic analysis and Blanchflower and Oswald (2004) make a direct connection between a person's utility and self-reported well-being by introducing a reported well-being function.

The sample consists of dependent employees who are in full-time employment and work for at least 35 hours per week. The sample is restricted to people who live in West Germany since, even 16 years after reunification, the perception of and the preferences concerning economic inequality may still be fundamentally different in East and West Germany. For the same reason, foreigners are excluded. An overview of descriptive statistics is in the appendix A.

\footnotetext{
${ }^{3}$ The data used in this paper was extracted from the SOEP Database provided by the DIW Berlin (http://www.diw.de/soep) using the Add-On package SOEP Menu v2.0 (Jul 2005) for Stata(R). SOEP Menu was written by Dr. John P. Haisken-DeNew (john@soepmenu.de). The following authors supplied SOEP Menu Plugins used to ensure longitudinal consistency, John P. Haisken-DeNew - h2817x p2266x p2278x p2282x p2291x p2294x p2297x p3468x p3469x p3471x p488x p527x p81x, Markus Hahn and John P. Haisken-DeNew (GENERATED) - p2267x. The SOEP Menu generated DO file to retrieve the SOEP data used here and any SOEP Menu Plugins are available upon request. Any data or computational errors in this paper are my own. Haisken-DeNew (2005) describes SOEP Menu in detail.
} 
The definition of the reference group is of central importance. For this purpose, the people with whom an individual compares him/herself have to be identified. Two kinds of reference groups are distinguished. Firstly, the geographical region is used as a classifier. ${ }^{4}$ In this case, the reference group consists of all employees who live in a geographical area, i.e., a district. This definition is based on the consideration that the people have a relatively sound knowledge of the socio-economic situation of those with whom they compare themselves. For example, they can observe the reference individuals' socio-economic life circumstances quite easily. Since social comparison is carried out between different occupational groups, income of perhaps very different occupations may be compared. Thus, the attitudes that come to light in such a comparison are of a rather general nature and might provide a picture of a global preference to income inequality.

Table 2 gives some descriptive statistics for the sample. For the entire period, 326 regional reference groups were generated based on geographical districts. On the average, 29.4 individuals are included in these regional entities per year. Not every reference group is available in every year. The average difference in (gross) labor income is 602 euro (in constant 2001 prices). Income inequality is calculated on the basis of a generalized entropy measure, the mean logarithmic deviation $\mathrm{I}(0)$, for the entire period (cf. Shorrocks 1984). This measure can be decomposed with respect to the reference groups and inequality can be calculated within and between the reference groups. The figures show that $92 \%$ of the inequality can be attributed to the inequality within the reference groups. Only a relatively small portion of $8 \%$ arises between the regions.

The second reference group is defined according to the occupation of the employees. Here, income inequality must be interpreted in a slightly different way because preferences regarding inequality capture the welfare effect of a variation in wages within an occupational group. The occupational groups are classified on the basis of the International Standard Classification of Occupations (ISCO-88) (cf. Elias 1997). 268 occupational reference groups are generated, which include 50.6 individuals per year on the average. The average difference in income is 553 euro, which is clearly smaller than in the case of the regional reference groups. The inequality measure $\mathrm{I}(0)$ indicates that $71 \%$ of the total in- 


\section{Table 2}

\section{Reference groups and income inequality}

\begin{tabular}{lrr}
\hline & \multicolumn{2}{c}{ reference groups } \\
\cline { 2 - 3 } & region & occupation \\
\hline number of groups & 326 & 268 \\
average group size & 29.4 & 50.6 \\
minimum group size & 2 & 2 \\
maximum group size & 176 & 192 \\
average difference in income (in euro) & 602 & 553 \\
\hline $\mathrm{I}(0)$ & 0.134 & 0.134 \\
$\mathrm{I}(0)$ Within & 0.123 & 0.095 \\
$\mathrm{I}(0)$ Between & 0.011 & 0.039 \\
\hline
\end{tabular}

Note: Inequality measure $\mathrm{I}(0)$ is calculated for the sample used in table 4 . Source: GSOEP 1995 to 2004.

equality is due to inequality within the occupational groups, while the inequality between the occupational groups is $29 \%$ of the total inequality.

The estimation of the parameters in equation 3 depends substantially on the specification of the error term $\eta$. In this context, it has to be considered that the data have a hierarchical structure. On the one hand, several longitudinal observations are nested within individuals and, on the other hand, individuals are nested in regional or occupational reference groups. For example, employees who live in the same district are equally affected by influences that are not controlled in the model-for example, the regional labor market situation and the future economic prospects in the region. If the unobserved heterogeneity in the levels of the individuals or the reference groups is relevant and not controlled for, the parameter estimates will be inefficient or even biased. To account for the dependencies on both levels, the error is specified as (vgl. Baltagi et al. 2001; Skrondal and Rabe-Hasketh 2004)

$$
\eta_{i}=\mu_{k}+v_{k i}+\varepsilon_{k i t}
$$

\footnotetext{
${ }^{4}$ The regional information is at a higher level of data security than the standard scientific use file of the GSOEP. Therefore, this part of the research was carried out at the DIW Berlin.
} 
$\mu_{k}$ and $v_{k i}$ denote the reference group-specific and individual-specific effects, respectively. ${ }^{5}$ Both are assumed to be time-invariant. $\varepsilon_{k i t}$ is the idiosyncratic error. It is further assumed that

$$
\mu_{k} \sim \mathrm{N}\left(0, \sigma_{\mu}^{2}\right), v_{k i} \sim \mathrm{N}\left(0, \sigma_{v}^{2}\right), \text { and } \varepsilon_{k i t} \sim \mathrm{N}\left(0, \sigma_{\varepsilon}^{2}\right)
$$

The resulting multi-level model was estimated using the command xtmixed implemented in the software package Stata. In addition, all model specifications were estimated without controlling for the influence of the reference group (i.e., without $\mu_{k}$ ). Based on a likelihood ratio test the hypothesis was tested whether $\sigma_{\mu}^{2}=0$. This could be rejected only for the regional reference group. As a result, all remaining models were estimated without the parameter $\mu_{k}$ and are, therefore, identical to usual random effects models.

Apart from modeling the unobserved heterogeneity as a random intercept, a fixed effects model is an alternative. The fixed effects approach provides a consistent estimator when the unobserved heterogeneity is correlated with the explanatory variables. However, Mundlak (1978) points out that the decision is not whether the individual effect is stochastic or fixed but rather whether the inferences are for the population or the sample. The true but unknown effect of the exogenous variables, i.e., the coefficient vector $\beta$ that is constant for all individuals, should not depend on the method of estimation. Both procedures will yield the same results if the model specification is correct. Differing coefficients are caused by an incorrect model specification. Thus, the question is not whether the estimation procedure is correct but rather whether the model specification is appropriate. Therefore, fixed effects estimators are presented and discussed for the model in table 4.

\footnotetext{
${ }^{5}$ This specification has a certain shortcoming as it assumes that a lower-level cluster is nested only in one higher-level cluster. In particular, an individual can only belong to one reference group. The specification and estimation of a more complex multiple-membership model is on the agenda for future study.
} 


\section{Estimation Results}

A yardstick for the results of the models that include the process of social comparison is provided by estimating equation 3 without the social comparison, i.e., without the parameters $\beta_{1}$ and $\beta_{2}$ (cf. table 3 ). In this estimation, results from other investigations are confirmed (cf. Clark 1996; Clark et al. 1996). The signs of the coefficients of the variables age and age squared indicate a U-shaped relationship between job satisfaction and age. The influence of logarithmic labor income is, as expected, highly significant and positive.

From a theoretical point of view, a decrease in satisfaction is expected when working hours increase. This hypothesis is confirmed very clearly. It is noticeable that the absolute value of the estimator for the coefficient of the working hours is larger than that for income. Since both variables are logarithmic, the quotient of the coefficients can be interpreted as an elasticity. On the basis of the coefficients estimated, the elasticity is $\partial \ln y / \partial \ln H=0.308 / 0.206=1.5$. As a consequence, an individual requires a super-proportional growth in wages when working hours increase so that his/her welfare remains constant.

Apart from further control variables, as for example, education, family status, health status etc., a variable that measures the number of years since the first interview in the GSOEP is included. The variable controls for panel and/or learning effects of persons who have been participating for a longer period in the study. Such effects may affect the data concerning the subjective well-being (cf. Ehrhardt et al. 2000). Thus, Landua (1993) points to the fact that there is a decline in the values for satisfaction that results solely from the repeated interviews. The quality of the data improves, however, after participation in several interview waves. As expected, the results point to a highly significant, negative impact of the number of years since the first interview on job satisfaction.

A dummy variable captures the effect of face-to-face interviews, i.e., whether the interview was carried out by an interviewer or whether the questionnaire was filled out by the respondent alone. The estimator indicates a positive impact when an interviewer was present. An explanation for this finding is that the respondents adopt an attitude of reserve and do not admit their discontentment in the presence of the interviewer. Possibly, the respondents are afraid that the interviewer may not comprehend their discontentment. 
In the following, the impact of the process of social comparison on job satisfaction operating through the mechanism of self-value is discussed. First, the analysis focuses on the regional reference groups. In a second step, income inequality in the occupational reference groups is considered in more detail. In addition, a model that investigates social comparison in both kinds of reference groups simultaneously is presented at the end of the section.

For the regional reference groups, the estimator of the coefficient $\beta_{1}$, which captures the welfare effect of the disadvantageous inequality, is highly significant and negative (cf. columns 2 and 3 in table 3). This means that the larger the average difference between one's own income and the income of richer people is, the lower one's job satisfaction is. Apparently, the individuals have feelings of envy towards richer people living in the same district. The comparison with poorer people is captured by the estimator for $\beta_{2}$. A positive welfare effect is indicated. The larger the average difference in income regarding the poorer reference people is, the higher job satisfaction is. This effect can be interpreted as a welfare gain that results from an increase in prestige.

\section{Figure 2}

Relative impact of income resulting from the material satisfaction of needs and social comparison on job satisfaction

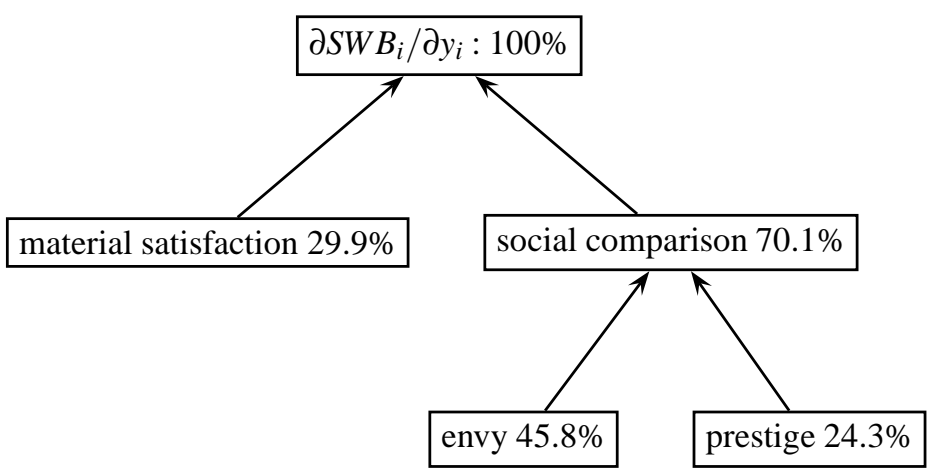

Note: Calculations on the basis of the estimation results for the regional reference group in table 3 for the median position.

From the analysis it follows that an increase in own income generates additional job satisfaction from both the loosening of the budget constraint (i.e., material satisfaction) and social comparisons (i.e., more prestige and less envy). In order to get an idea of the relative size of these effects, the additional welfare from a marginal increase in labor income is calculated for a representative individual that takes the median position in the 
reference group. From this follows that the number of people with a higher income is equal to the number of people with a lower income. On this assumption, the number of people in the reference group is $n=2 i-1$ and there are $n-i-1$ persons who are wealthier and just as many who are poorer. The marginal utility of an increase in income is

$$
\begin{aligned}
\frac{\partial S W B_{i}}{\partial y_{i}} & =\frac{i-n}{n-1} \beta_{1}+\frac{i-1}{n-1} \beta_{2}+\beta_{3} \frac{1}{y_{i}} \\
& =\frac{1}{2}\left(\beta_{2}-\beta_{1}\right)+\beta_{3} \frac{1}{y_{i}} .
\end{aligned}
$$

The welfare effects of an increase in income can be decomposed according to equation 6 into three components whose relative weights can be evaluated. The calculation assumes that the median position has a (gross) labor income of 2000 euro. Firstly, the increase in welfare due to the loosening of the budget constraint (i.e., due to the additional material satisfaction) is $30 \%$ of the total effect. ${ }^{6}$ Secondly, the increase in income reduces the feelings of envy towards the richer people in the reference group. The decrease in the average difference between one's own income and income of persons who are wealthier leads to a reduction of the disadvantageous inequality and induces a positive welfare effect that is approximately $46 \%$ of the total effect. The increase in the advantageous inequality and the welfare gain from the additional prestige provides another $24 \%$ of the total welfare effect. The calculation demonstrates the dominating welfare effect that results from the process of social comparison with the richer reference individuals. The (West German) employees seem to be considerably more satisfied with their jobs when the inequality of the regional income is advantageous to themselves, i.e., when they earn more money than the people in their neighborhood. On the other hand, satisfaction diminishes with an increase in the average income difference with respect to richer individuals.

\footnotetext{
${ }^{6}$ The relative material welfare effect calculated on the basis of the estimators $\hat{\beta}_{1}=-0.098, \hat{\beta}_{2}=$
} $0.052, \hat{\beta}_{3}=0.064$ and a labor income of $y_{i}=2$ (in 1000) is

$$
\frac{0.064 / 2}{0.5 \cdot(0.052+0.098)+0.064 / 2}=0.299 \text {. }
$$


Table 3

Job satisfaction and social comparison

\begin{tabular}{|c|c|c|c|c|c|c|}
\hline \multirow[b]{3}{*}{ variable } & \multicolumn{6}{|c|}{ reference group } \\
\hline & \multicolumn{2}{|c|}{ region } & \multicolumn{2}{|c|}{ occupation } & \multicolumn{2}{|c|}{ none } \\
\hline & coefficient & s.e. & coefficient & s.e. & coefficient & s.e. \\
\hline disadvantageous inequality $\beta_{1}^{R}$ & $-0.098 * *$ & $(0.032)$ & $0.059 *$ & $(0.026)$ & - & \\
\hline advantageous inequality $\beta_{2}^{R}$ & $0.052 * *$ & $(0.016)$ & $0.048 * *$ & $(0.016)$ & - & \\
\hline $\log$ of labor income (in 1000) $\beta_{3}$ & $0.064+$ & $(0.050)$ & $0.193 * *$ & $(0.045)$ & $0.206 * *$ & $(0.035)$ \\
\hline $\log$ of working hours & $-0.342 * *$ & $(0.088)$ & $-0.319 * *$ & $(0.089)$ & $-0.308 * *$ & $(0.088)$ \\
\hline number of years of education & $-0.018 * *$ & $(0.006)$ & $-0.022 * *$ & $(0.007)$ & $-0.020 * *$ & $(0.007)$ \\
\hline age & $-0.021 *$ & $(0.010)$ & $-0.025^{*}$ & $(0.010)$ & $-0.025^{*}$ & $(0.010)$ \\
\hline age squared & $0.000+$ & $(0.000)$ & $0.000+$ & $(0.000)$ & $0.000^{*}$ & $(0.000)$ \\
\hline sex: female & -0.013 & $(0.034)$ & -0.012 & $(0.035)$ & -0.010 & $(0.035)$ \\
\hline \multicolumn{7}{|l|}{ marital status (reference: single) } \\
\hline married & $0.069+$ & $(0.040)$ & $0.100^{*}$ & $(0.041)$ & $0.092 *$ & $(0.040)$ \\
\hline married, but separated & $0.318 * *$ & $(0.083)$ & $0.344 * *$ & $(0.083)$ & $0.339 * *$ & $(0.082)$ \\
\hline divorced & $0.116^{*}$ & $(0.057)$ & $0.141 *$ & $(0.058)$ & $0.129 *$ & $(0.057)$ \\
\hline widowed & 0.145 & $(0.141)$ & 0.176 & $(0.142)$ & 0.186 & $(0.141)$ \\
\hline log of household size & $0.132 * *$ & $(0.037)$ & $0.125^{* *}$ & $(0.037)$ & $0.125 * *$ & $(0.036)$ \\
\hline number of children under 18 & -0.011 & $(0.019)$ & -0.011 & $(0.019)$ & -0.013 & $(0.019)$ \\
\hline house owner & 0.021 & $(0.029)$ & $0.065^{*}$ & $(0.028)$ & $0.064 *$ & $(0.028)$ \\
\hline \multicolumn{7}{|l|}{ health status (reference: very good) } \\
\hline good & $-0.460 * *$ & $(0.031)$ & $-0.461 * *$ & $(0.031)$ & $-0.459 * *$ & $(0.031)$ \\
\hline satisfactory & $-0.997 * *$ & $(0.035)$ & $-0.994 * *$ & $(0.035)$ & $-0.994 * *$ & $(0.035)$ \\
\hline poor & $-1.545^{* *}$ & $(0.045)$ & $-1.531 * *$ & $(0.046)$ & $-1.543 * *$ & $(0.045)$ \\
\hline bad & $-2.099 * *$ & $(0.097)$ & $-2.077 * *$ & $(0.099)$ & $-2.098 * *$ & $(0.098)$ \\
\hline \multicolumn{7}{|l|}{ labor force status (reference: low) } \\
\hline training & $0.339 * *$ & $(0.068)$ & $0.338 * *$ & $(0.068)$ & $0.393 * *$ & $(0.065)$ \\
\hline middle & 0.051 & $(0.031)$ & 0.045 & $(0.032)$ & 0.040 & $(0.031)$ \\
\hline high & $0.219 * *$ & $(0.043)$ & $0.212 * *$ & $(0.044)$ & $0.217 * *$ & $(0.043)$ \\
\hline \multicolumn{7}{|c|}{ branch of industry (reference: all the others) } \\
\hline other industries & 0.020 & $(0.039)$ & 0.006 & $(0.039)$ & 0.008 & $(0.039)$ \\
\hline chemical industry & 0.027 & $(0.070)$ & 0.000 & $(0.071)$ & -0.000 & $(0.070)$ \\
\hline trade & $-0.103 * *$ & $(0.040)$ & $-0.109 * *$ & $(0.040)$ & $-0.106^{* *}$ & $(0.040)$ \\
\hline financial services & 0.011 & $(0.060)$ & -0.027 & $(0.062)$ & -0.010 & $(0.061)$ \\
\hline public sector & $0.060+$ & $(0.032)$ & $0.066+$ & $(0.033)$ & $0.057+$ & $(0.033)$ \\
\hline \multicolumn{7}{|l|}{ firm size (reference: 20-199) } \\
\hline$\leqslant 5$ & $0.060+$ & $(0.035)$ & $0.066^{*}$ & $(0.035)$ & $0.065+$ & $(0.035)$ \\
\hline 200-1999 & $0.057+$ & $(0.032)$ & $0.061+$ & $(0.032)$ & $0.061+$ & $(0.032)$ \\
\hline$\geqslant 2000$ & 0.016 & $(0.033)$ & -0.006 & $(0.033)$ & -0.002 & $(0.033)$ \\
\hline \multicolumn{7}{|c|}{ worry about job security (reference: not concerned) } \\
\hline somewhat concerned & $-0.413 * *$ & $(0.022)$ & $-0.410 * *$ & $(0.022)$ & $-0.411 * *$ & $(0.022)$ \\
\hline very concerned & $-1.043 * *$ & $(0.033)$ & $-1.035^{* *}$ & $(0.034)$ & $-1.033 * *$ & $(0.033)$ \\
\hline face-to-face Interview & $0.306 * *$ & $(0.024)$ & $0.313^{* *}$ & $(0.024)$ & $0.315^{* *}$ & $(0.024)$ \\
\hline $\begin{array}{l}\text { number of years since first } \\
\text { interview }\end{array}$ & $-0.011 * *$ & $(0.002)$ & $-0.009 * *$ & $(0.003)$ & $-0.010 * *$ & $(0.003)$ \\
\hline$\hat{\sigma}_{\mu}$ & 0.208 & $(0.022)$ & & & & \\
\hline$\hat{\sigma}_{v}$ & 1.128 & $(0.014)$ & 1.131 & $(0.014)$ & 1.127 & $(0.014)$ \\
\hline$\hat{\sigma}_{\varepsilon}$ & 1.412 & $(0.006)$ & 1.425 & $(0.006)$ & 1.428 & $(0.006)$ \\
\hline Log restricted likelihood & \multicolumn{2}{|c|}{-64971.493} & \multicolumn{2}{|c|}{-64481.928} & \multicolumn{2}{|c|}{-65282.784} \\
\hline $\mathrm{N}$ & \multicolumn{2}{|c|}{33868} & \multicolumn{2}{|c|}{33594} & \multicolumn{2}{|c|}{33993} \\
\hline
\end{tabular}

Note: Job satisfaction is endogenous variable. Significance: $* * \leqslant 1 \%, * \leqslant 5 \%,+\leqslant 10 \%$.

All models include dummy variables for the panel year.

Source: GSOEP 1995 to 2004. 
Table 4

Simultaneous social comparison within regional and occupational reference group

\begin{tabular}{|c|c|c|c|c|}
\hline \multirow[b]{2}{*}{ variable } & \multicolumn{2}{|c|}{ random effects } & \multicolumn{2}{|c|}{ fixed effects } \\
\hline & coefficient & s.e. & coefficient & s.e. \\
\hline region: disadvantageous inequality $\beta_{1}^{R}$ & $-0.132 * *$ & $(0.031)$ & -0.051 & $(0.040)$ \\
\hline region: advantageous inequality $\beta_{2}^{R}$ & 0.025 & $(0.029)$ & 0.005 & $(0.035)$ \\
\hline occupation: disadvantageous inequality $\beta_{1}^{O}$ & $0.062 *$ & $(0.026)$ & $0.070^{*}$ & $(0.033)$ \\
\hline occupation: advantageous inequality $\beta_{2}^{O}$ & 0.034 & $(0.029)$ & -0.000 & $(0.034)$ \\
\hline $\log$ of labor income (in 1000) $\beta_{3}$ & 0.070 & $(0.054)$ & $0.288 * *$ & $(0.078)$ \\
\hline $\log$ of working hours & $-0.327 * *$ & $(0.090)$ & $-0.271^{*}$ & $(0.115)$ \\
\hline number of years of education & $-0.020 * *$ & $(0.007)$ & 0.005 & $(0.017)$ \\
\hline age & $-0.026^{*}$ & $(0.010)$ & - & \\
\hline age squared & $0.000 *$ & $(0.000)$ & -0.000 & $(0.000)$ \\
\hline sex: female & -0.004 & $(0.036)$ & - & \\
\hline \multicolumn{5}{|l|}{ marital status (reference: single) } \\
\hline married & $0.093 *$ & $(0.041)$ & 0.031 & $(0.065)$ \\
\hline married, but separated & $0.358 * *$ & $(0.084)$ & $0.294 * *$ & $(0.113)$ \\
\hline divorced & $0.140 *$ & $(0.059)$ & 0.119 & $(0.099)$ \\
\hline widowed & 0.176 & $(0.145)$ & 0.190 & $(0.319)$ \\
\hline log of household size & $0.121 * *$ & $(0.037)$ & 0.008 & $(0.051)$ \\
\hline number of children under 18 & -0.007 & $(0.019)$ & $0.051+$ & $(0.027)$ \\
\hline house owner & $0.062 *$ & $(0.029)$ & $0.115^{* *}$ & $(0.044)$ \\
\hline \multicolumn{5}{|l|}{ health status (reference: very good) } \\
\hline good & $-0.453 * *$ & $(0.031)$ & $-0.331 * *$ & $(0.035)$ \\
\hline satisfactory & $-0.977 * *$ & $(0.035)$ & $-0.715^{* *}$ & $(0.041)$ \\
\hline poor & $-1.510 * *$ & $(0.046)$ & $-1.131 * *$ & $(0.054)$ \\
\hline bad & $-2.043 * *$ & $(0.099)$ & $-1.561 * *$ & $(0.113)$ \\
\hline \multicolumn{5}{|l|}{ labor force status (reference: low) } \\
\hline training & $0.320 * *$ & $(0.069)$ & $0.475 * *$ & $(0.093)$ \\
\hline middle & 0.044 & $(0.032)$ & 0.040 & $(0.040)$ \\
\hline high & $0.208 * *$ & $(0.045)$ & $0.198 * *$ & $(0.056)$ \\
\hline \multicolumn{5}{|l|}{ branch of industry (reference: all the others) } \\
\hline other industries & 0.007 & $(0.039)$ & 0.027 & $(0.054)$ \\
\hline chemical industry & -0.004 & $(0.072)$ & -0.088 & $(0.107)$ \\
\hline trade & $-0.101 *$ & $(0.041)$ & -0.022 & $(0.058)$ \\
\hline financial services & -0.019 & $(0.064)$ & 0.091 & $(0.124)$ \\
\hline public sector & $0.065+$ & $(0.034)$ & 0.032 & $(0.055)$ \\
\hline \multicolumn{5}{|l|}{ firm size (reference: $20-199$ ) } \\
\hline$\leqslant 5$ & $0.063+$ & $(0.035)$ & -0.043 & $(0.049)$ \\
\hline 200-1999 & $0.067 *$ & $(0.032)$ & $0.172 * *$ & $(0.042)$ \\
\hline$\geqslant 2000$ & 0.005 & $(0.034)$ & $0.123^{* *}$ & $(0.047)$ \\
\hline \multicolumn{5}{|c|}{ worry about job security (reference: not concerned) } \\
\hline somewhat concerned & $-0.407 * *$ & $(0.022)$ & $-0.337 * *$ & $(0.025)$ \\
\hline very concerned & $-1.028 * *$ & $(0.034)$ & $-0.909 * *$ & $(0.039)$ \\
\hline face-to-face Interview & $0.308 * *$ & $(0.024)$ & $0.248 * *$ & $(0.031)$ \\
\hline number of years since first interview & $-0.010 * *$ & $(0.003)$ & $-0.034+$ & $(0.019)$ \\
\hline
\end{tabular}

Note: Job satisfaction is endogenous variable. $\mathrm{N}=32901$. Significance: $* * \leqslant 1 \%, * \leqslant 5 \%,+\leqslant 10 \%$.

All models include dummy variables for the panel year.

Source: GSOEP 1995 to 2004. 
In order to provide further insight into the mechanism of self-value and the process of social comparison, an occupational reference group was also generated. It has to be noticed that the social comparison has a statistically significant influence on the job satisfaction in the occupational reference group. The upward comparison again seems to dominate the downward comparison, which can be seen from an evaluation of the estimators for $\beta_{1}$ and $\beta_{2}$, respectively.

The highly significant, positive estimator for disadvantageous inequality is of special interest in this model. The larger the average difference in income regarding the richer comparison group is, the higher job satisfaction is. A possible explanation for this result is the information effect discussed in Section 2. Evidently, employees in an occupational group derive welfare increasing information about their future income from an unequal distribution of income. The fact that there are persons in the reference group who make more money than they do is interpreted as a chance for a future improvement in their own financial situations. Apparently, they hope to benefit from income inequality in the future-either by a gain in prestige or an improvement in material welfare. The evaluation of the size of the coefficients of the advantageous and the disadvantageous inequality indicates that the hope for a future income improvement has an even greater influence on job satisfaction than the prestige effect. It also follows that the prestige effect cannot compensate for the loss of hope for a financial improvement. (The loss of hope of an improvement is an inevitable consequence of the realization of the improvement.) While both future prospects and actual success in the job have a positive impact on job satisfaction, envy seems to play no or only a minor role for persons in the same occupation since the information effect is the dominant outcome of disadvantageous inequality.

Finally, the social comparison within the regional and the occupational reference group is analyzed simultaneously (cf. table 4). The random effects estimation very clearly confirms the dominance of upward social comparison. The coefficients of disadvantageous inequality are highly significant for both the regional and the occupational reference group. The downward comparison with poorer reference people is of only minor importance for the individuals' job satisfaction. Obviously, individuals compare themselves primarily with persons who are more financially successful. The welfare effects derived from disadvantageous inequality remain different with respect to the reference group. In- 
come inequality is clearly welfare decreasing in the context of a regional reference group whereas it improves job satisfaction within an occupational group.

These results are supported by fixed effects estimation. The upward social comparison dominates in the perception of welfare. The distribution of income within an occupational group has a clearly positive impact on job satisfaction.

\section{Discussion}

The results of this study indicate that individuals make social comparisons that affect their well-being. Remarkably, the perception of disadvantageous income inequality depends on the reference group. On the one hand, individuals have an aversion to disadvantageous income inequality in the region they live in, while on the other hand they prefer inequality in their occupational group. It is suggested that this positive welfare effect is based on the expectation of a favorable development of one's own income in the future (information effect).

Furthermore, upward comparison dominates downward comparison regarding the absolute impact on well-being. Apparently, disadvantageous income inequality has a stronger (positive or negative) impact on the individual welfare than advantageous inequality. This seems to imply loss aversion as argued in the prospect theory (cf. Kahneman and Tversky 1979; Tversky and Kahneman 1992).

In the case of a regional reference group, the income comparison takes place primarily between persons with different occupations. As there is no evidence for feelings of envy among persons with the same occupation, the conclusion can be drawn that people are envious of people from other occupations. Individuals seem to disapprove of the disadvantageous variation in wages between different occupations. Obviously, people suppose income inequality in the nearby region to be unfair.

Frank (1991) calls the dependence of welfare on relative income and/or consumption "positional externalities" because of their affinity with external environmental effects. In analogy to the public good problem, he recommends public policy intervention (cf. Frank 1997). In this sense, the legitimacy of a sizeable variation in income seems to be questionable when the citizens have to accept a loss in welfare due to an external effect of the distribution of income. Rich people often argue that their incomes are legitimated 
by the (labor) market. The opinion, however, that market distribution can function as a yardstick for a fair distribution of income must be doubted when the aversion to a regional disadvantageous income inequality is considered. 


\section{A Descriptive Statistics}

\section{Table 5}

\section{Descriptive statistics}

\begin{tabular}{|c|c|c|c|c|}
\hline variable & mean & s.e. & $\min$. & $\max$. \\
\hline job satisfaction & 7.161 & 1.955 & 0 & 10 \\
\hline log of gross labor income (in 1000) & 0.839 & 0.558 & -2.973 & 3.798 \\
\hline log of working hours & 3.749 & 0.136 & 3.555 & 4.382 \\
\hline number of years of education & 12.250 & 2.623 & 7 & 18 \\
\hline age & 39.236 & 11.179 & 17 & 65 \\
\hline age squared & 1664.389 & 901.104 & 289 & 4225 \\
\hline sex: female & 0.317 & 0.465 & 0 & 1 \\
\hline \multicolumn{5}{|l|}{ marital status } \\
\hline single & 0.323 & 0.467 & 0 & 1 \\
\hline married & 0.572 & 0.495 & 0 & 1 \\
\hline married, but separated & 0.018 & 0.131 & 0 & 1 \\
\hline divorced & 0.079 & 0.270 & 0 & 1 \\
\hline widowed & 0.010 & 0.099 & 0 & 1 \\
\hline log of household size & 0.923 & 0.494 & 0 & 2.398 \\
\hline number of children under 18 & 0.614 & 0.920 & 0 & 8 \\
\hline house owner & 0.506 & 0.500 & 0 & 1 \\
\hline \multicolumn{5}{|l|}{ health status } \\
\hline very good & 0.125 & 0.331 & 0 & 1 \\
\hline good & 0.493 & 0.500 & 0 & 1 \\
\hline satisfactory & 0.290 & 0.454 & 0 & 1 \\
\hline poor & 0.082 & 0.274 & 0 & 1 \\
\hline bad & 0.010 & 0.099 & 0 & 1 \\
\hline \multicolumn{5}{|l|}{ labor force status } \\
\hline training & 0.055 & 0.228 & 0 & 1 \\
\hline low & 0.181 & 0.385 & 0 & 1 \\
\hline middle & 0.517 & 0.500 & 0 & 1 \\
\hline high & 0.247 & 0.431 & 0 & 1 \\
\hline \multicolumn{5}{|l|}{ branch of industry } \\
\hline other industries & 0.123 & 0.329 & 0 & 1 \\
\hline chemical industry & 0.037 & 0.190 & 0 & 1 \\
\hline trade & 0.115 & 0.319 & 0 & 1 \\
\hline financial services & 0.061 & 0.239 & 0 & 1 \\
\hline all the others & 0.664 & 0.474 & 0 & 1 \\
\hline public sector & 0.287 & 0.452 & 0 & 1 \\
\hline \multicolumn{5}{|l|}{ firm size } \\
\hline$\leqslant 5$ & 0.185 & 0.389 & 0 & 1 \\
\hline $20-199$ & 0.280 & 0.449 & 0 & 1 \\
\hline 200-1999 & 0.248 & 0.432 & 0 & 1 \\
\hline$\geqslant 2000$ & 0.287 & 0.452 & 0 & 1 \\
\hline \multicolumn{5}{|l|}{ worry about job security } \\
\hline not concerned & 0.504 & 0.500 & 0 & 1 \\
\hline somewhat concerned & 0.382 & 0.486 & 0 & 1 \\
\hline very concerned & 0.114 & 0.317 & 0 & 1 \\
\hline face-to-face interview & 0.555 & 0.497 & 0 & 1 \\
\hline number of years since first interview & 7.742 & 6.245 & 0 & 20 \\
\hline
\end{tabular}

Note: Calculations for the sample without social comparison in table $3(N=33993)$.

Source: GSOEP 1995 to 2004. 


\section{References}

Baltagi, B. H., Heun Song, S., Cheol Jung, B., 2001. The unbalanced nested error component regression model. Journal of Econometrics 101 (2), 357-381.

Blanchflower, D. G., Oswald, A. J., 2004. Well-being over time in Britain and the USA. Journal of Public Economics 88 (7-8), 1359-1386.

Clark, A., Oswald, A., Warr, P., 1996. Is job satisfaction U-shaped in age? Journal of Occupational \& Organizational Psychology 96 (1), 57-81.

Clark, A. E., 1996. Job satisfaction in Britain. British Journal of Industrial Relations 34 (2), 189-217.

Clark, A. E., Oswald, A. J., 1996. Satisfaction and comparison income. Journal of Public Economics 61 (3), 359-381.

Dakin, S., Arrowood, A., 1981. The social comparison of ability. Human Relations 34 (2), 89-109.

D'Ambrosio, C., Frick, J. R., 2004. Subjective well-being and relative deprivation: An empirical link. IZA Discussion Papers 1351, Institute for the Study of Labor (IZA).

Easterlin, R. A., 1974. Does economic growth improve the human lot? Some empirical evidence. In: David, P. A., Reder, M. W. (Eds.), Nations and Households in Economic Growth: Essays in Honor of Moses Abramovitz. Academic Press, New York.

Ehrhardt, J. J., Saris, W. E., Veenhoven, R., 2000. Stability of life-satisfaction over time. Journal of Happiness Studies 6 (2), 177-205.

Elias, P., 1997. Occupational classification (ISCO-88): Concepts, methods, reliability, validity and cross-national comparability. OECD Labour Market and Social Policy Occasional Papers 20, OECD Directorate for Employment, Labour and Social Affairs.

Fehr, E., Schmidt, K. M., 1999. A theory of fairness, competition, and cooperation. The Quarterly Journal of Economics 114 (3), 817-868.

Festinger, L., 1954. A theory of social comparison processes. Human Relations 7 (2), 117-140.

Frank, R. H., 1991. Positional externalities. In: Zeckhauser, R. (Ed.), Strategy and Choice: Essays in Honor of Thomas C. Schelling. MIT Press, Cambridge, pp. 25-47.

Frank, R. H., 1997. The frame of reference as a public good. Economic Journal 107 (445), 1832-1847.

Frey, B. S., Stutzer, A., 2002. What can economists learn from happiness research? Journal of Economic Literature 40 (2), 402-435. 
Haisken-DeNew, J. P., 2005. SOEP Menu: A menu-driven Stata/SE interface for accessing the German Socio-Economic Panel. mimeo.

URL http: / / www . soepmenu. de

Haisken-DeNew, J. P., Frick, J. R., 2005. DTC. Companion to the German SocioEconomic Panel Study (GSOEP).

URL http://www.diw.de/english/sop/service/dtc/

Hirschman, A., Rothschild, M., 1973. The changing tolerance for income inequality in the course of economic development. With a mathematical appendix. Quarterly Journal of Economics 84 (4), 544-566.

Infratest Sozialforschung, 2004. Living in Germany. Survey 2004 on the social situation of households. Individual question form.

URL http://www.diw.de/deutsch/sop/service/fragen/index.html

Kahneman, D., Tversky, A., 1979. Prospect theory: An analysis of decision under risk. Econometrica 47 (2), 263-91.

Landua, D., 1993. Veränderung von Zufriedenheitsangaben in Panelbefragungen. Eine Analyse über nicht beabsichtigte Effekte des Längsschnittdesigns. Kölner Zeitschrift für Soziologie und Sozialpsychologie 45 (3), 553-571.

Loewenstein, G. F., Bazerman, M. H., Thompson, L., 1989. Social utility and decision making in interpersonal contexts. Journal of Personality and Social Psychology 57 (3), 426-441.

Luttmer, E. F. P., 2005. Neighbors as negatives: Relative earnings and well-being. The Quarterly Journal of Economics 120 (3), 963-1002.

Mundlak, Y., 1978. On the pooling of time series and cross section data. Econometrica 46 (1), 69-85.

Runciman, W. G., 1966. Relative Deprivation and Social Justice. Routledge \& Kegan Paul, London.

Senik, C., 2005. Income distribution and well-being: What can we learn from subjective data? Journal of Economic Surveys 19 (1), 43-63.

Shorrocks, A. F., 1984. Inequality decomposition by population subgroups. Econometrica 52 (6), 1369-1385.

Singer, J. E., 1966. Social comparison - progress and issues. Journal of Experimental Social Psychology Supplement 1, 103-110.

Skrondal, A., Rabe-Hasketh, S., 2004. Generalized Latent Variable Modeling. Interdisciplinary Statistics Series. Chapman \& Hall, Boca-Raton.

Tversky, A., Kahneman, D., 1992. Advances in prospect theory: Cumulative representation of uncertainty. Journal of Risk and Uncertainty 5 (4), 297-323. 
van de Stadt, H., Kapteyn, A., van de Geer, S., 1985. The relativity of utility: Evidence from panel data. The Review of Economics and Statistics 67 (2), 179-87.

Veblen, T., 1994. The Theory of the Leisure Class. Penguin Books, New York.

Yitzhaki, S., 1979. Relative deprivation and the Gini coefficient. The Quarterly Journal of Economics 93 (2), 321-24. 